\title{
Electrical Developments in the Soviet Union
}

$\mathrm{T}$ $\mathrm{HE}$ growth in the use of electrical energy in the Soviet Union in connexion with the Government's industrial development schemes were outlined in a paper read to the Institution of Electrical Engineers by Mr. Allan Monkhouse on January 10. He gave interesting details also of the development in the use of peat fuel in large power stations. The first State-planning organisation set up by the Government was the State commission for the electrification of Russia appointed in 1921. In forming this commission, Lenin emphasised the necessity of providing an abundant supply of cheap electrical power as a basis on which industry could develop. From 1923 onwards the construction of fifty-six large power stations and the erection of 8,000 miles of hightension overhead wires with all their distributing substations has been a most spectacular development. The rapid growth in the use of electrical power during the last ten years is shown by the increase in the monthly winter output, from 750 million units to 11,000 million units.

The industrial districts of the north, which comprise Leningrad, Moscow, the cotton manufacturing district centred at Ivanovo Vosnesensk and the Gorki (Nijni Novgorod) district, where many large engineering works are being constructed, are far removed from the bituminous and anthracite coalfields of the Ukraine or the oilfields situated on the shores of the Caspian Sea. For economic and strategic reasons, it was considered necessary to make the northern industrial areas independent of these fuel supplies. Special attention was therefore concentrated on the development of stations burning peat and brown coal.

A survey of the peat areas of the U.S.S.R. indicates that approximately 42 per cent of the world's peat resources are located in that country. It is calculated that 30,460 million tons of fuel are available south of lat. $60^{\circ} \mathrm{N}$. North of this line, the vast peat resources of the tundra have as yet only been partially surveyed. Using a special form of shaft-chain grate, it was found that the efficiency obtained was quite satisfactory. The Balakna power station in the Nijni Novgorod district is the largest peat-burning power station in the world. Its present capacity of $158,000 \mathrm{kw}$. is being increased to $204,000 \mathrm{kw}$. Of the eighty-one official stations, approximately 30 per cent operate on peat fuel. A special process of peatwinning known as the hydro-peat process has been developed. The peat is dislodged from the bog with a high-pressure sluicing apparatus, and the mixture of peat and water is then pumped into specially prepared drying fields. After a few days' drying, a special form of tractor with cutter wheels is driven over the field and leaves the peat in such a form that it can be raked up easily and finally air-dried. The shortcomings found initially in using peat in a power station have been in large measure overcome, mainly by experimental research.

In the Ukraine and the mining districts of the Don basin, much work has been done in utilising the anthracite-waste spoil-banks, which have accumulated over a period of many years, but the efficiencies obtained have been rather disappointing.

Large areas of the cities of Moscow and Leningrad are already heated with hot water circulated from the central power stations. On the outskirts of these cities, large new so-called thermal-electric stations are being built for heating the new residential districts. In Moscow the hot water leaves the water-heating plant in the central power station at a temperature, varying according to conditions, of between $85^{\circ}$ and $120^{\circ} \mathrm{C}$., and after making a circuit of some two miles, it returns at a temperature of $30^{\circ}-35^{\circ} \mathrm{C}$. The pipes are laid in special conduits in the street and are covered with thermal insulation. Many of the large new industrial towns are being built with the idea of all their buildings being heated from central thermal-electric power stations.

With the exception of the Ural Mountains and the Caucasus, both of which are far removed from the central industrial areas, there is not enough mountainous country to make high-head hydroelectric power stations possible. But the Soviet Government has decided to build a series of large low-head hydro-electric stations on the great rivers of European Russia. The dam built on the Dnieper and those being built on the Volga and the Svir have a twofold object in view, namely, providing cheap electric power and making the rivers navigable for large vessels. Of the low-head stations, that on the Dnieper is the most important. The pressure of transmission is 161 kilovolts, and the station supplies the works of the Dnieper Combine and the central Ukrainian network.

A most important undertaking in Central Asia is the Chirchick fertiliser works, designed to produce large quantities of nitrate fertiliser for the cotton fields of Central Asia. The first station has been begun and the turbines will work with a head of 66 metres. The scheme provides for irrigating $1,250,000$ acres of cotton growing land. It is interesting to notice that the Soviet authorities have called in Italian consulting engineers to lay out the hydro-electric part of this great scheme.

Some progress has been made in standardising 
methods. The line linking the new Svir hydroelectric station with Leningrad uses the very high voltage of 220 kilovolts. The Soviet intends to electrify about 2,300 miles of railway before 1937 . The pressure of 1,500 volt direct current is generally used for suburban electrification, but the voltage for the long distance main lines has not yet been fixed.

Mr. Monkhouse laid stress on the extreme importance the Soviet authorities attach to research and experimental work. Academic and fundamental research work is receiving the closest attention, and very large electrical research laboratories have been developed. All the various works and factories connected with the Electrotechnical Trust send their more complicated problems to the Central Institute in Moscow. The laboratories employ 1,700 workers, about 800 of whom are men with university training. The departmental chiefs are, almost without exception, men who occupy professorial chairs in the universities. There is little doubt that, in electrical development, more has been achieved than in many other branches of the country's economic life.

\section{News and Views}

\section{"Letters to the Editor"}

ON two occasions last year, issues of NATURE were published in which "Letters to the Editor" occupied considerably more than the usual proportion of the journal. This week we are printing a Supplement of sixteen pages, fifteen of which are occupied by correspondence-and there are still many letters in type awaiting publication. The number of letters we receive for this part of the journal reflects fairly accurately, we believe, contemporary progress of research in all departments of science. Last year we printed no less than 597 columns of correspondence, the great majority of which announced new lines of work or made significant contributions to older established knowledge. The addresses at the ends of the letters in this week's Supplement alone indicate the world-wide distribution of our correspondents. The spate of letters brings its own difficulties, and we are frequently obliged to ask correspondents to reduce the length of communications, but nevertheless we are gratified to find our columns so much in demand. It reaffirms the old saying that science over-rides all national barriers. Recently, a short section has been introduced at the end of "Letters to the Editor", in which brief mention is made of points brought out in some of the longer letters in the preceding pages. Correspondents will realise the difficulties involved in obtaining suitable notes, and they are invited to submit paragraphs about fifty words in length which they regard as summarising the main conclusions of their communications, for possible use in this section of the journal when their letters appear.

\section{Royal Astronomical Society's Medal Awards}

THE Gold Medal of the Royal Astronomical Society has been awarded to Prof. E. A. Milne, Rouse Ball professor of mathematics, University of Oxford, for his work on radiative equilibrium and theory of stellar atmospheres. A Jackson Gwilt (bronze) Medal has been awarded to Mr. Walter Frederick Gale, of Waverley, N.S.W., for his discoveries of comets and his work for astronomy in New South Wales. Prof. Milne has occupied his present chair since 1929, having then moved to Oxford from Manchester, where he had been professor of applied mathematics.
Before going to Manchester, however, he was university lecturer in astrophysics at Cambridge and assistant director of the Solar Physics Observatory. His contributions to mathematical physics and astrophysics are of particular value on account of the close contacts they represent between observational work and theoretical conceptions. His essay as Smith's prizeman at Cambridge in 1922 embodied a treatment of radiative equilibrium which has proved the starting point for the greater part of the more recent work on stellar atmospheres. In his Bakerian lecture of the Royal Society in 1929, on the opacity of stellar atmospheres, Prof. Milne further developed a method of determining stellar temperatures and pressures, depending largely on the study of the contours of spectrum lines, that is, on the determination of their intensities at different distances from the centre of the lines. Of a different character is the model of the universe conceived by Prof. Milne and developed in a lecture entitled "WorldGravitation by Kinematic Methods" delivered before the London Mathematical Society in May last. The striking simplicity of the method used in the construction of this statistical model, and the farreaching character of its interpretations, open up a new vista of possibilities for cosmic research.

Mr. Gale, the Jackson Gwilt medallist of the Royal Astronomical Society, belongs to the enthusiastic band of non-professional, or amateur, astronomers who have contributed so much to observational astronomy. $\mathrm{He}$ is the discoverer of three comets-in 1894, 1912 and 1927-and has given close attention to the planet Mars, especially during the southern oppositions of 1892, 1894 and 1907. As first secretary, and afterwards president, of the New South Wales branch of the British Astronomical Association, Mr. Gale has done much to encourage the practical study of the heavens in New South Wales, as well as to promote interest in astronomy among the general public.

\section{Geological Society's Awards}

The Geological Society of London has this year made the following awards: Wollaston Medal to (Continued on $p$. 111.) 